\title{
Reduto de travestis: das origens fabris ao repositório de imaginários de um bairro Amazônico
}

\author{
Travesti stronghold: from factory origins to the imaginary repositor of an Amazonian \\ neighborhood
}

\author{
Osvaldo Vasconcelos \\ https://orcid.org/0000-0002-4125-8986 \\ Universidade Federal do Pará
}

\begin{abstract}
Resumo: A proposta deste estudo, apontamentos da tese em andamento, é analisar os diversos imaginários criados acerca da travestilidade, da cidade de Belém e do bairro do Reduto, local onde as travestis, sujeitos desta pesquisa, se prostituem. Refletiremos sobre a territorialidade, produzida e pensada enquanto processo histórico e sobre as identidades criadas no interior da cidade partindo da urbanização e do imaginário que cria e recria a realidade a partir das experiências do passado e também dos indivíduos. Nesse sentido, este trabalho abordará a cidade, o bairro e as vidas que internamente tecem o viver cotidiano e de que maneira tais vidas são limitas por interesses vários.

Palavras-Chave: Imaginário. Travestis. Bairro do Reduto.
\end{abstract}

Abstract: The purpose of this study, notes of the thesis in progress, is to analyze the various imaginary created about travestilidade, from the city of Belém and the neighborhood of Reduto, where travestis, subjects of this research, prostitute themselves. We will reflect on the territoriality, produced and thought as a historical process and on the identities created within the city from the urbanization and the imaginary that creates and recreates reality from the experiences of the past and also from individuals. In this sense, this work will address the city, the neighborhood and the lives that internally weave daily life and how these lives are limited by various interests.

Keywords: Imaginary. Travestis. Neighborhood of Reduto.

Aqui é nosso lugar. Tentamos ficar mais ali na frente, mas é aqui no Reduto que deixam a gente grelhar em paz, sabe? Também, né, tudo escuro, velho, deserto, quem vai se incomodar de ver travesti andando de um lado pro outro fazendo programa?

Carol Luggeri, em entrevista ao pesquisador, em 01/05/2019.

As travestis que se prostituem no bairro do Reduto escolheram este local e nele permanecem por três décadas. Contudo, para que se compreenda como essa permanência manteve-se por anos, é preciso que se pensem, antes de qualquer coisa, nos motivos que as levaram a chegar, uma vez que foram expulsas de outro lugar, e nos motivos que as fizeram permanecer. A hipótese aqui levantada está diretamente relacionada ao bairro, personagem central na história da cidade de Belém, que possuiu diversos status, do mais generoso, como o bairro que carregou consigo a riqueza 
produzida pelo ciclo da borracha (Sarges, 2002), ao mais depreciativo, como o bairro da boemia e da prostituição de travestis (Ferreira, 2008).

Neste trabalho, analisaremos o conceito de imaginário, pois tanto as travestis, quanto o bairro, estão intrinsecamente relacionados no imaginário popular. Quais seriam, portanto, esses imaginários? Para tentar responder essa pergunta, recorremos a Gilbert Durand, Cornelius Castoriadis e Paes Loureiro. As perspectivas destes autores acerca do imaginário não são necessariamente distintas, mas os dois primeiros analisam o imaginário no plano geral, e o terceiro no âmbito amazônico. Em seguida, abordaremos a história do bairro do Reduto e sua importância para a memória da cidade de Belém e em qual momento há a união do bairro com as travestis.

Autores como Fábio Castro, Nazaré Sarges e Rubens Ferreira nos auxiliarão, pois os dois primeiros afirmam que a ascensão e queda do bairro são resultados direto da condução econômica empreendida pelos governantes locais e o último afirma que o atual cenário decadente do bairro é responsável pela presença das travestis ali. Tentaremos compreender os meandros dessas abordagens, recorrendo, ainda, aos interlocutores/as dessa pesquisa ${ }^{1}$, como na fala mais acima de Carol Luggeri, para responder a pergunta que norteará esta seção.

\section{Dos muitos imaginários}

Para Gilbert Durand (2002), o imaginário é fruto da angústia, da consciência cruel que o homem tem da finitude da sua existência, ou, mais precisamente, da morte. Além disso, o autor trabalha com a noção do devir, termo filosófico que tipifica as mudanças pelas quais as coisas passam. Juntos, morte e devir, para o autor, são responsáveis pela criação dos imaginários que o indivíduo cria com o intuito de atenuar a desesperança de viver eternamente, criando, dessa forma, espaços reconfortantes, que negarão seu lento desaguar rumo ao crepúsculo. Durand defende que essas premissas imaginativas são oriundas da percepção, da constante apreensão e reprodução de símbolos, imagens, tradições e mitos que formam o pensamento arquetípico do homem (Durand, 2002). Feito isso, tem-se o imaginário, que segundo o autor, é responsável "fiel da balança neural", pelo equilíbrio mental do homem diante do tempo vivido e, por conseguinte, da certeza de um fim.

Perscrutando o termo imaginário, o autor disseca-o para mostrar-nos a fisiologia social com a qual concebemos as certezas nas quais alicerçamos razões e emoções. Durand conceitua imaginário como "um conjunto de imagens e das relações de imagens que constitui o capital pensado do homo sapiens" (Durand, 2002). Para ele, o imaginário, mesmo sendo formado por recortes outros de existência, é dotado de vida e autonomia próprias. Ainda de acordo com ele, imagem e pensamento fazem parte do mesmo lócus, sendo a imagem a responsável pela significação inicial e o pensamento pela faculdade criadora e, juntos, formarão um caldo complexo (Durand, 2002).

Com uma abordagem menos metafísica, quando comparado a Gilbert Durand, mas também centrada nas emoções, Cornelius Castoriadis (1982) conceitua imaginário como uma criação abstrata, indefinida, indeterminada de imagens, figuras, formas, sobre as quais só é possível pensar "alguma coisa". De acordo com o autor, o que

\footnotetext{
${ }^{1}$ As entrevistas, de modo geral, foram feitas a partir de 2014, durante o mestrado, mas foram necessárias novas conversas, realizadas em maio e junho do ano corrente, com três interlocutores para o presente trabalho, sendo duas travestis e um representante do Movimento Homossexual do Pará (GHP). O nome deste último foi alterado e substituído por um pseudônimo a pedido do informante.
} 
entendemos por "realidade" e "razão" são oriundos desse imaginário difuso. O autor ainda argumenta que tudo aquilo que está posto, que nos é mostrado, encalacrado no universo social, é intrínseco ao simbólico. Para ele, esse fato não é um fim em si, mas sem essa lógica é possível um pensamento fora da rede simbólica. Pensado de outro jeito, uma miríade de instituições que convivem conosco em sociedade, são apinhadas de elementos simbólicos e estes, por sua vez, são apinhados de imaginários, invenções, construções (Castoriadis, 1982).

O imaginário, ainda de acordo com Castoriadis, usa o simbólico não apenas para ostentar uma visibilidade, mas também para existir, para deixar de ser virtual e se transformar em qualquer realidade outra. Por outro lado, continua o autor, o simbolismo presume qualquer capacidade imaginativa, pois implica na faculdade de olhar para algo e imaginar o que ele não é, de pensá-lo diferente do que ele é (Castoriadis, 1982).

Partindo da premissa dos dois autores, incorremos sobre os imaginários criados acerca dos lugares nos quais estamos inseridos e sobre os quais elaboramos imagens, pensamentos, certezas. O bairro que nasceu e sobreviveu sob a égide da opulência econômica, foi permeado de imaginários vários que variavam de símbolo da riqueza gomífera (Sarges, 2002), ao retrato dos desdobramentos econômicos da Belle Époque (Castro, 2010), mas que com o declínio dessa economia e com a urbanização de Belém, aliado ao seu tombamento histórico, tempos depois, ganhou novos significados, também fruto do imaginário local, como lugar abandonado, boêmio e "cheio de fornicadores" (Ferreira, 2008).

Dessa forma, recorremos ao imaginário amazônico proposto por João de Jesus Paes Loureiro (2010) que o entende como surgido do inconsciente coletivo do povo da floresta, resultado de variáveis simbólicas, enraizadas no que se entende por natureza, sincretismo cultural de origem negra, indígena e européia. $O$ autor enumera o rio, a floresta e a exuberância natural amazônicas como uma espécie de delírio a que é submetido aquele que ali vive, participante daquela realidade, notadamente o autóctone. Esses seres vivenciam aquela realidade, lançando mão dos sentidos, criando sensibilidades várias, onde o som, o cheiro, os encantos da floresta, dos animais, os mistérios da vida podem ser explicáveis pela experiência com essa sensibilidade, diariamente repetida, tal qual um mito.

Ainda de acordo com Loureiro, muito do que foi e ainda é escrito sobre a Amazônia e por extensão sobre a população que aqui vive, é embebido no discurso colonialista, que por sua vez foi e é "contaminado" pela hegemonia dos relatos dos viajantes que pelos rios amazônicos velejaram, tornando perene a fabricação de subalternidades imagéticas do homem e da região como um todo, que através da repetição constante, reverberará no imaginário popular maior, incluindo aí o imaginário local acerca de si mesmo. Como resultado, aponta o autor, tem-se um ideal do ser amazônico pautado em inviabilizações e na dificuldade de se construir um senso crítico que problematize a reflexão que parta do contexto local para o global (Loureiro, 2010).

\section{Dos imaginários da cidade de Belém}

Belém, capital do Estado que é louvada em seu hino como a "princesa louçã da Amazônia", é retratada no imaginário popular com muita generosidade. Ouve-se falar em "cidade das mangueiras", "Paris dos trópicos", "Metrópole da Amazônia", atualmente rebaixada ao título de "Metrópole da Amazônia Oriental", posto que Manaus é a metrópole da Amazônia Ocidental. O mito criado em torno de Belém não se restringe 
somente à cidade em si, mas ao seu povo, visto como um digno "homem cordial" (Holanda, 2010).

Entretanto, a cordialidade sugerida por Sérgio Buarque de Holanda (2010), pensada para o povo brasileiro como um todo, pode ser aplicada à população local, visto que sua fama de cortês, acolhedora e alegre lhe é amplamente difundida e, internamente, alimentada (Castro, 2010). Entretanto, a expressão sempre foi marcada pela dubiedade, mesmo o autor sendo bem objetivo quanto ao seu significado, uma vez que foi o tom crítico da sagacidade, do tirar proveito do Outro, de passar-lhe a perna para dar-se bem, sua real intenção (Holanda, 2010). Nesse sentido, Fábio Castro (2010), ao explicar o pensamento de uma parte significativa da população de Belém, afirma que o pensamento aristocrático, de querer fazer parte de uma elite endinheirada que não mais existe, ao menos não como antes, faz com que haja a reprodução de uma cordialidade seletiva, visando sempre um uma boa colocação diante do outro, de preferência quando esse outro é oriundo de outros Estados.

Corroborando tal premissa, Loureiro (2010) pensa o aspecto fantástico, ilusório, da estreita relação do homem amazônico com a floresta, que produz um imaginário ambivalente acerca do jeito de ser do amazônida, sempre alegre, hospitaleiro, acolhedor, mas que esconde uma persona real, carregada de humanidade. Dessa forma, tanto o povo, quanto a cidade, configuram-se na "ficção e não-ficção" pensada por Umberto Eco (1985), quando este autor analisa as (re)criações da vida cotidiana, ou de "mundos possíveis", que são as características presentes no mundo vivido, ornados por convenções e postulados individuais, que juntos formarão mundos outros.

Fábio Castro (2010) afirma que Belém tem predileção por se descrever com as cores mais fortes do sonho, da fantasmagoria, que por sua vez são resultado das muitas experiências econômicas e traumáticas, nesse caso representado naquilo que ficou conhecido como Ciclo da Borracha, que acabaram moldando os discursos que a cidade mantém acerca de si. $\mathrm{O}$ autor compreende Belém como uma cidade dual, que tem sua existência pautada em imaginários conflitantes, na qual

[...] teceu-se uma modernidade ambígua, marcada pelo encontro entre a encenação do antimundo (o moderno exterior e distante) e fragorosa sensação de derrota ante ao processo colonizador, ante a domesticação do mundo natural amazônico - uma derrota, não obstante, relativa, se se considerar os resultados realmente obtidos. (Castro, 2010, p. 132)

Castro entende a cidade de Belém como uma extensão de Lisboa, em Portugal, na qual os portugueses vieram reconstruir seu modo de vida, mas, ao notarem uma vegetação selvagem, por exemplo, estabeleceram uma fronteira entre o mundo civilizado, o mundo deles, e o mundo bizarro, aquele mundo no qual agora estavam. As elites locais, continua o autor, sempre viveram a dualidade pensada para a cidade, que por um lado era vista com um futuro rico e promissor e, por outro, como um fracasso retumbante tendo como grande responsável a natureza (Castro, 2010).

A partir dessa perspectiva dual, a elite local não mediu esforços para transformar Belém numa réplica de Paris, via recursos da economia gomífera (Castro, 2010). Os políticos locais, afirma o autor, principalmente Antônio Lemos, reurbanizaram a cidade tal qual Haussmann ${ }^{2}$ fez na capital francesa, construindo e reorganizando a capital local. Outra característica refere-se ao estilo de vida que somente o dinheiro em abundância

\footnotetext{
${ }^{2}$ Então prefeito de Paris, responsável pela reorganização da capital francesa tal como é conhecida hoje.
} 
poderia proporcionar, como, por exemplo, mandar lavar as ruas da cidade com perfumes e enviar trouxas de roupas sujas para a Europa (Castro, 2010), pois a água da cidade não era adequada para lavar as indumentárias dos ricos locais, muito menos os lençóis nos quais seus corpos deitavam.

Por certo, tais estilos, urbanístico e de vida, não puderam se sustentar quando o ciclo da borracha chegou ao fim, em meados do século XX. Castro afirma que a nova realidade foi um peso por demais pesado para a elite, pois o pensamento local era tal que acreditava-se que nascer em Belém e Lisboa era praticamente a mesma coisa e agora a crise financeira os despertava de um sonho na selva. O autor ainda faz um chamamento para uma característica tipicamente portuguesa e que encontrou no pensamento local terra fértil para florescer, a melancolia (Castro, 2010).

Quando a consciência coletiva detectou a iminência do esgotamento da fartura, afirma Castro, um mito português foi resgatado para confortar consciências e corações órfãos da riqueza de outrora: o sebastianismo. Por tal mito, diz o autor, o povo português acredita que D. Sebastião, rei de Portugal, desaparecido na batalha de Alcácer-Quibir, retornará e salvará seu povo da situação de precariedade e instabilidade política (Castro, 2010).

É a esse mito, diz o autor, que a elite local depositou suas esperanças vãs de reverter a periclitante situação financeira na qual se encontrava. Entretanto, a situação não foi revertida e Belém, desde então, permaneceu envolvida nessa névoa de injustiça que muitos representantes da elite local, afirma o autor, debatem-se. Ele destaca que o pensamento sebastianista que paira sobre Belém é tipicamente oriundo da elite, que não se conforma com a realidade que foi e é obrigada a viver, mas não nega que o pensamento aristocrático tenha contaminado os menos favorecidos (Castro, 2010), pois ser rico é impossível a muitos, mas pensar como um rico é livre, barato e acessível a todos.

Sobrevivendo com o pouco dinheiro que sobrou, com a fama de opulenta e com as marcas de uma riqueza vistas ainda hoje em diversos pontos da cidade, Belém, como qualquer capital, foi-se ampliando e se urbanizando. Dessa vez não mais com o planejamento urbano pensado por Antônio Lemos, mas como uma típica cidade brasileira que cresce desordenadamente, refletindo um rápido aumento populacional, que por sua vez sempre ocorrerá quando houver uma nova possibilidade de exploração econômica (Picoli, 2008), como ocorre em diversas cidades amazônicas, como Altamira, canteiro de obras da usina hidrelétrica de Belo Monte; a exploração mineral como as que ocorrem em Parauapebas, Marabá e Eldorado do Carajás, todas no Estado do Pará. Em todos esses municípios houve um aumento populacional drástico em virtude dos projetos minerais e de infraestrutura (Picoli, 2008), o mesmo ocorrendo com Belém quando da exploração da borracha (Castro, 2010).

Em virtude da acelerada expansão urbana, a cidade amazônica engole florestas ${ }^{3}$, aterra córregos, cimenta solos e transforma a paisagem. Há núcleos urbanos com significativo inchaço populacional, fazendo com que o centro, antes concentrador

\footnotetext{
${ }^{3} \mathrm{O}$ processo de aceleração urbana na Amazônia é usualmente demarcado com a chegada dos militares à região na década de 1960 (Picoli, 2008). O processo de abertura de estradas, com a consequente supremacia da malha rodoviária em detrimento da malha dendrítica, ocasionou numa mudança drástica no estilo de vida do homem amazônico (Loureiro, 2010), pois as cidades mais importantes, antes localizadas às margens dos rios, ou deixaram de existir, ou perderam significativamente sua importância ante aquelas que surgiram às margens das novas rodovias, como a Transamazônica, fato que reverberou nas grandes cidades da região, como Belém, que vertiginosamente viu crescer sua população, incrementada com sucessivas levas migratórias, bem como com a urbanização.
} 
de comércios, serviços e habitações, seja continuamente deixado para trás. Como resultado disso, conjuntos habitacionais, shoppings e uma grande variedade de serviços deslocam-se para as outrora áreas afastadas (Rodrigues, 2000). Fenômeno observado em qualquer grande cidade em expansão, as áreas de obsolescência, que abrigam os invisíveis moradores de rua, viciados em drogas, usurpadores de bens materiais alheios e a prostituição, vão-se encalacrando na paisagem, sendo encarados por muitos como personagens comuns e naturais.

Especificamente às áreas de obsolescências, Miguel Ângelo Ribeiro (2002) afirma que esses lugares, normalmente degradados, com arquitetura em franca decadência e desertos, são os locais escolhidos pela prostituição, seja ela feminina, masculina ou de travestis. O autor argumenta que enquanto essas áreas não são alvo da gentrificação ${ }^{4}$, esses profissionais do sexo encontram ali um lugar no qual poderão trabalhar em suas atividades, normalmente noturnas, sem causar maiores incômodos ao restante dos moradores, além do fato de que a prática da prostituição em si, para a sociedade, combina com esses cenários, posto que é encarada como tão degradante quanto (Ribeiro, 2002).

Em relação à prostituição, como observado por Rubens Ferreira (2008), é possível fazer uma linha cronológica junto ao crescimento da capital paraense. Antes concentrada num ponto específico, a prostituição, de mulheres e travestis, coabitava um território, na Rua Riachuelo, bairro da Campina. Em virtude de uma série de conflitos entre os dois grupos, as segundas foram migrando, a partir de 1999, para o bairro do Reduto, onde ainda hoje permanecem (Ferreira, 2008).

Contudo, em virtude do contínuo crescimento urbano, é possível perceber outros pontos de prostituição travesti em Belém, como na Avenida Pedro Álvares Cabral, no bairro do Telégrafo; nas transversais ao longo da Avenida Almirante Barroso, no bairro do Marco; na Avenida Augusto Montenegro, bairro do Parque Verde; e na parte boêmia do bairro de São Braz. Em todos esses logradouros, bem como nos logradouros de outras cidades brasileiras, é possível perceber que independente da organização do grupo, a degradação urbana é semelhante (Ribeiro, 2002).

\section{Dos imaginários do bairro do Reduto}

Este trabalho se concentra no bairro do Reduto, considerado pioneiro na prostituição de travestis e que reina no imaginário local como "o lugar das travestis" (Ferreira, 2008). Esse bairro faz parte de um conjunto histórico-arquitetônico, composto ainda por Cidade Velha e Campina, tombado pelo IPHAN ${ }^{5}$. Quando do surgimento da cidade, a partir de 1616, a Cidade Velha, sendo o primeiro bairro, passou a ser o local de moradia da nascente cidade. Após rápida urbanização, a Campina passou a ser uma extensão do primeiro. Já o Reduto foi transformado num bairro fabril, onde os grandes

\footnotetext{
4 Termo oriundo do inglês "gentrification". Refere-se aos locais degradados, nas grandes cidades, que são alvo da revitalização urbana com fins turísticos e imobiliários e que expulsam para lugares distantes aqueles que ali habitam ou circulam, normalmente a população de baixa renda, usuários de drogas e profissionais ligados à prostituição (Hasbaert, 2009).

${ }^{5}$ Esse tombamento foi publicado no Diário Oficial da União via Ministério da Cultura no dia 10/05/2012, mas bem antes, no dia 18/05/1994, na administração do então prefeito Hélio da Motta Gueiros, foi promulgada a Lei do Patrimônio Histórico de Belém, na qual consta, dentre outras medidas legais, os limites do Centro Histórico, bem como as medidas punitivas ante um possível desrespeito à memória da cidade, sanções já previstas no Plano Diretor do município de Belém. No entanto, como é possível atestar numa visita ao Reduto, tais punições não são postas em prática, uma vez que o surgimento de prédios que ultrapassem os 6 (seis) andares nos limites do bairro, como asseverado nas leis municipal e federal, são visíveis.
} 
empresários mantinham suas fábricas e armazéns (Sarges, 2002).

É possível perceber numa das extremidades do bairro, a zona portuária, ainda ativa. Contrariamente ao restante da cidade, que de acordo com o IBGE, possui uma crescente demográfica, o Reduto faz o caminho inverso, sendo o bairro que mais reduz o número de habitantes (Brasil, 2018). De acordo com o instituto, o Reduto possui poucas habitações, creditado ao fato do bairro ser tombado, o que inviabiliza novos empreendimentos imobiliários, bem como alterações nas edificações, além de uma população que envelhece ano após ano.

Historicamente concebido como industrial e popular, o bairro do Reduto foi, durante mais de dois séculos, uma área periférica, seja por sua arquitetura fabril, seja por sua topografia de igapó ${ }^{6}$, esse último fato sendo responsável pelos constantes alagamentos registrados em sua história a contar pelo igarapé que o atravessava Igarapé das Almas -, bem como pela Baía do Guajará contígua a ele (Trindade Jr. e Silva, 2005).

Entretanto, em 1963, durante o governo de Alacid Nunes, prefeito de Belém à época, houve uma tímida revitalização do bairro, com a drenagem do Igarapé das Almas, o que resolveu o problema dos constantes alagamentos e alçou o bairro à condição de área de transição entre a periferia e o centro da cidade, passando a ter acessibilidade e infra-estrutura jamais vistas (Monteiro, 2013) o que favoreceu, também, a nascente especulação imobiliária que até hoje mira o bairro.

Segundo Castro, Antônio Lemos, intendente da cidade de Belém entre os anos de 1897 e 1911, foi o responsável pelo maior programa de reestruturação urbana que a cidade já teve. Beneficiada pelos lucros robustos oriundos da economia gomífera (Ciclo da Borracha), Belém foi alvo dos sonhos megalomaníacos do intendente, que imaginou uma "Paris na Amazônia" e não mediu esforços para concretizá-la (Castro, 2010). Dentre as obras de maior destaque e ainda hoje visíveis, há as ruas largas (boulevares), o Teatro da Paz, inspirado no Teatro Scalla da cidade de Milão, na Itália, e as praças da República e Batista Campos. Contudo, para alcançar tal feito, argumenta o autor, Lemos lançou mão de leis que impediam, por exemplo, que "pessoas feias andassem nas ruas por onde a elite circulava" (Castro, 2010, p. 210).

Entretanto, no final da década de 1960, os bairros centrais de Belém foram sistematicamente reorganizados, com o claro objetivo de valorizar tais áreas, sendo os pobres os alvos humanos preferenciais, posto que ocupavam as baixadas, que por sua vez eram os alvos territoriais. A valorização dessas áreas objetivava um lugar melhor no qual a elite local pudesse habitar, mesmo que para isso os mais pobres fossem expulsos para áreas cada vez mais distantes, como de fato ocorreu. Essas pessoas foram remanejadas para a Primeira Légua Patrimonial, atualmente onde está localizado um dos lugares mais caros da cidade, o Bairro do Marco, no qual, obviamente, os descendentes desses pobres, tão sem recursos quanto, não mais estão (Castro, 2010).

Traço comum nas cidades brasileiras que mais se urbanizam, a descaracterização da arquitetura histórica, cerne da identidade e do passado das urbes, é mais intenso quanto mais alto o poder aquisitivo dos moradores, pois a busca pela sofisticação e pela marca do moderno nas novas edificações joga à margem o caráter histórico e as capacidades simbólica e política das arquiteturas mais antigas (Bresciane, 1994). No bairro do Reduto não é diferente, pois mesmo existindo leis que o protegem,

\footnotetext{
${ }^{6}$ Segundo José Júlio Toledo (2009), há três tipos topográficos básicos na região amazônica. Há a topografia de Terra Firme, que não alaga; topografia de Várzea, que alaga no período chuvoso (inverno amazônico); e a topografia de Igapó, que é constantemente alagada.
} 
a especulação imobiliária é forte e avança com rapidez.

Diante do impedimento legal de construção de novas edificações no seio do bairro, o Reduto foi, aos poucos, sendo transformado num bairro boêmio, deixando paulatinamente para trás seu passado fabril, mesmo ainda existindo galpões e armazéns das poucas indústrias que restaram, e outras tantas que foram transformadas em empreendimentos outros, como faculdades, órgãos públicos e estabelecimentos comerciais de diversos segmentos. Mas é a boemia do bairro que permeia o imaginário local atualmente, aliado aos dados do IBGE já apresentados anteriormente, o que imprime a baixa densidade demográfica e seu relativo vazio demográfico, percebido mais claramente no período noturno.

A partir da década de 2000, segundo o Grupo Homossexual do Pará (2013) o Reduto passou a receber um número crescente de boates voltadas ao público LGBT e outras tantas para o público em geral ${ }^{7}$. Além, é claro, de um número variado de bares e casas de festas e motéis. O bairro, impedido de se urbanizar dentro dos ditames do capital imobiliário, e também pelas severas restrições impostas pelo IPHAN, além de altamente dispendiosas do ponto de vista econômico (Monteiro, 2013), serviu de abrigo para grupos marginalizados socialmente, como travestis, usuários de drogas, garotos de programa e homossexuais de modo geral, que encontraram ali um espaço para sociabilidade.

\section{Dos imaginários sociais às vidas reais}

Eu moro no Guamá, mas eu grelho e desgrelho aqui, no Reduto. É aqui que sou travesti. No Guamá eu sou Fabrício, a gay. No Reduto, sou Fádia Knowles, a travesti, a Beyoncé da Amazônia, tu percebeu meu sobrenome? Toda travesti, mesmo dizendo que é travesti o tempo todo, só é travesti mesmo, aqui. Olha pro lado. Onde tu viu tanta travesti junta? Só aqui mesmo, mano. (Fádia Knowles, entrevista ao pesquisador em 03/06/2019)

No imaginário local, o bairro do Reduto é visto como um lugar que teve um passado rico, que foi abandonado em virtude da desconcentração fabril e que hoje abriga bares e boates gays, além da prostituição travesti. Um local perigoso, como é preconizado nos relatórios policiais (SEGUP, 2018). Não que seja uma inverdade, pois áreas degradadas carregam consigo essa premissa, como atesta Ribeiro (2002).

No entanto, em meio aos mitos acerca do imaginário criado em relação ao bairro, é possível inferir, baseado no tipo de entretenimento e nas pessoas que cotidianamente sociabilizam no período noturno, que, sim, o bairro é um gueto, como atesta Howard Becker (2008), ao classificar os excluídos marginalizados que procuram lados para onde se agrupar. De acordo com este autor, a sociedade impõe regras, que por sua vez têm seus pontos fora da curva, representados pelo "desvio", que produzirão o "outsider". Este representa aquele que, por dado motivo, foge dessas regras sociais que é entendida como arbitrária, indo ao encontro de outros "outsiders" e, juntos, formarão uma comunidade (Becker, 2008).

Ampliando o pensamento do autor e exemplificando com o que está sendo analisado aqui, as travestis seriam esses "outsiders", que juntamente com os garotos de programa e os gays que vão sociabilizar nas boates do bairro do Reduto, formam

\footnotetext{
7 Há o registro das boates Mysthical, Reduto, Gueto, Lux Club, Docto Street, Spin Louge, Malícia Pub, Amnésia Pub, Fetiche, Louvre, essas exclusivamente para o público homossexual. Contudo, há as boates voltadas para outros públicos, como: Templários, Villa Aurora, Trânsito, Tribunal.
} 
uma comunidade maior, daqueles que são afastados para um lugar distante, ou em franca degradação, formando o que Becker chama de "guetos urbanos" (Becker, 2008).

O GHP, liderado pelo ativista Patrício Oliva, informou, em entrevista concedida para esta pesquisa, que o anuário elaborado pelo grupo acerca do histórico dos bares e boates LGBT, concentrados no bairro do Reduto, em sua maioria, refletem uma política adotada pelos órgãos públicos no tocante ao afastamento dessa comunidade do contato mais direto com a sociedade como um todo:

Agora pensa: por que "autorizar" as boates gays somente em certos lugares, como o Reduto, o Guamá? Nós recebemos muitas denúncias de moradores do Umarizal [bairro nobre da capital] reclamando que muitos gays, quando saem das boates do Reduto, pois ficam no limite entre os dois bairros, ficam se beijando "à luz do dia, no meio da Doca" [Avenida importante do bairro do Umarizal], incomodando as pessoas que ficam horrorizadas olhando tudo dos seus apartamentos. Eles fazem denúncia exclusivamente sobre as gays. Não há denúncia desse tipo contra as travestis. Não podemos nos beijar? Por que os heterossexuais podem e nós não podemos? Por que os locais de sociabilidade dos heterossexuais podem ser em qualquer lugar e os nossos precisam ser confinados em locais na periferia ou no detonado Reduto? As travestis que se prostituem ali fazem sexo com os "homens de família" do outro lado [Umarizal]. Elas não afrontam assim na cara dura, entendes? O dinheiro que as bichas gastam nas boates são transformados em impostos que vão beneficiar todos. Então por que essa política separatista de nos colocar nesses lugares? (Patrício Oliva, entrevista ao pesquisador em 19/06/2019)

A crítica que o ativista faz expõe uma visão sobre como a política de afastamento empreendida pela prefeitura da cidade funciona. Os locais de sociabilidade homossexual são preferencialmente autorizados em locais que não agridam os demais moradores. No entanto, o bairro do Reduto faz fronteira com o bairro do Umarizal, um dos metros quadrados mais caros e nobres da cidade, separados apenas por uma grande avenida, Visconde de Souza Franco, popularmente conhecida como "Doca".

No tocante às travestis, Patrício argumenta que as denúncias dos moradores não se estendem a elas, acusando, inclusive, muitos dos "homens de família" do outro lado de, durante a madrugada, fazerem sexo com as travestis, esse fato não causando constrangimento às vistas sensíveis dos moradores, pois os homens que as procuram, casados e heterossexuais, estão protegidos em carros com ar condicionado e vedados pelas películas escuras nos vidros. Outro dado destacado pelo ativista diz respeito ao fato de as travestis não "afrontarem" os moradores como os demais homossexuais fazem. Contudo, isso talvez seja um ponto positivo nesse grupo, pois geralmente a realidade delas é mais complexa do que esse detalhe faz supor.

Marcia Ochoa (2004) problematiza a distinção entre os que são automaticamente excluídos - e os que se autoexcluem - daqueles que se reconhecem como "atores políticos" do ambiente. A autora incorre tal análise numa avenida movimentada da cidade de Caracas, na Venezuela, na qual muitas travestis ${ }^{8}$ se prostituem. Tal qual acontece no bairro do Reduto, Ochoa destaca o conflito existente entre moradores do entorno e as travestis. Em ambos há alegação de que a prática da prostituição afronta "os bons costumes", sendo que no trabalho de Ochoa há o destaque para a polícia.

Há de se fazer uma distinção no papel da polícia militar no bairro do Reduto, uma vez que em várias oportunidades, durante a pesquisa de campo, as viaturas da ronda

\footnotetext{
${ }^{8} \mathrm{~A}$ autora utiliza o termo "transformista", que é como as travestis são chamadas naquele país.
} 
ostensiva circulavam por lá. Mas, diferentemente do que ocorre no trabalho de Ochoa (2004), no Reduto a polícia assume uma "parceria" com as travestis. Há ligações dos moradores fazendo denúncias quase que diariamente, como afirma Carol Luggeri: "Eles ligam, os cana [policiais] vem aqui, mas as meninas resolvem rapidinho o babado". Sobre os motivos das ligações, Carol responde: "Eles dizem que a gente faz boquete na rua. $E$ antes que penses que eles tão mentindo, tem bicha amadora que chupa mesmo, viu? Viado novo, mano, sabe como é". Quando questiono sobre a chegada da polícia, após denúncia dos moradores do entorno, Carol mostra-se irritada: "Égua! Tu é cego, mano? Esses viado vão lá chupar esses caralho. É a propina: boquete".

Acerca desta afirmação de Carol Luggeri, anotei em diversas oportunidades no diário de campo o número da viatura que passava lentamente, realizando o policiamento ostensivo. O número era quase sempre o mesmo, diferindo em duas oportunidades, sempre com os mesmos policiais. Em dada oportunidade, enquanto estávamos conversando no cruzamento de duas ruas escuras, uma viatura da polícia estacionou a poucos metros de nós. Carol Luggeri olhou para Fádia Knowles e disse: "Tua grade, apertada, vai logo". Era a vez de Fádia Knowles pagar propina à polícia. Ela foi caminhando até o carro, que estava com a porta do carona aberta, atrás da qual um policial se postava em pé. Houve uma rápida troca de palavras e Fádia se abaixou. Por volta de 20 minutos depois, ela retornava para o nosso grupo e o carro da polícia saía acelerado.

Quando realizei a entrevista individual com Fádia Knowles, questionei a respeito desse dia, perguntando sobre como funcionava o rodízio e a "grade" para o "pagamento da propina". Ela afirma:

Todo dia eles passam aqui. Todo dia, menino. Eu gosto de pagar essa propina. Ele tem um pau imenso. Mas tem bicha que faz a pura e fica de mimimi. O babado é assim, ó: esses caralho nem passavam por aqui. Teve um tempo que eu nem via polícia aqui, mas aí as bicha quiseram avançar, avançar, aí ficou perto da Doca, né? Um tempo depois, mano, esses cana começaram a rondar por aqui. Olha como sou sortuda. Quando eles chegaram foi comigo que eles falaram. Disseram um bocado de babado, que os moradores tavam reclamando, esse papo todo. Mas, mano, fui criada no Guamá, pensa que sou otária? Se eles quisessem mesmo fazer onda não chegavam de fala mansa e risinho pro meu lado. Tá certo que sou gostosa mesmo, mas mesmo assim. Aí ele veio com um papo furado, de que podiam prender a gente, porque os moradores são de família com dinheiro. Quando ele acabou de falar eu disse "deixa eu ver teu pau". Rapidinho ele botou o bicho pra fora. E ainda tava durão! Chupei horrores e ele ainda disse que ia voltar. Mas sabe o que era o voltar deles? Voltar pra ter o pau chupado. Não tô te dizendo, menino? Esses caralhos aí ligam reclamando de nós e a polícia chega pra resolver. E resolve? Porra nenhuma. Quem resolveu foi minha língua de veludo. Aí eu falei pra esses viado que todo mundo ia chupar pica porque eu não era Jesus pra morrer na cruz por ninguém, mesmo a cruz sendo uma pica imensa, mano. E tu nem sabe dos babados. Com o tempo eles ficaram amigos nossos. Mandei eles cobrar propina das viadinhos e sabe o que um deles me disse? "quero viado com peito grande, pra apertar. Viado sem peito já basta aqueles ali do Malícia [boate localizada no bairro] que a gente aborda e eles vem logo chupando". Tu acreditas, menino? Nem pra chupar policial na pedra [com vontade] essas viadinhos servem. [grifo meu] (Fádia Knowles entrevista ao pesquisador em 17/12/2016)

No trabalho de Ochoa (2004), a polícia assume um caráter bastante conhecido em países em desenvolvimento, que é a truculência, permanecendo ao lado daqueles que são entendidos como "cidadãos de bem". Não que a polícia que age no bairro do Reduto tenha pacificado seu modus operandi, mas os interesses são outros. Os 
policiais, ao ignorarem as queixas dos moradores, justificáveis ou não, junto às travestis, usando estas para práticas que não se coadunam com aquelas que a corporação preconiza, lançam mão de práticas subalternizantes, usufruindo do poder que a farda Ihes confere para satisfazer seus desejos e em troca oferecer uma proteção que todo cidadão tem direito.

O policiamento, nesse caso, é diferenciado do trabalho de Ochoa especificamente no resultado, pois em Caracas há o embate entre travestis e policiais, estes últimos sempre sendo os vencedores. No bairro do Reduto, não. O policiamento ganha outros contornos, mesmo tendo o mesmo objetivo. Nesse sentido, afirmam Jacqueline Muniz e Eduardo Paes-Machado (2010) acerca da prática do policiamento ostensivo: "O policiamento caracteriza-se, assim, como uma expressão pragmática, funcional, utilitária e invasiva do como sustentar a submissão, sob algum consentimento, às regras do jogo" (Muniz; Paes-Machado, p. 3). Dessa forma, resgatando os sujeitos de direitos destacados por Ochoa (2004), os moradores do entorno do bairro raramente serão alvos de uma abordagem policial simplesmente por transitarem, ou serão incomodados em seus lares para algum tipo de averiguação. O mesmo não correndo com as travestis, que são duplamente subalternizadas na abordagem policial, pois além de estarem numa posição de desprestígio perante a sociedade, uma vez que se prostituem e são travestis, ainda precisam ressignificar a abordagem policial com trocas sexuais.

Nessa perspectiva, João Silvério Trevisan (2011) vaticina que elas são o retrato mais cruel da homossexualidade no Brasil, que a elas é destinado, na cidade, a falta de higiene das ruas e becos, a execração familiar, bem como um destino muitas vezes nocivamente associado às suas existências, a prostituição:

Evidentemente, a questão não é simples, porque a prostituição acaba se tornando uma profissão quase inerente ao travestismo [sic] enquanto estilo de vida, no Brasil. Geralmente vindos das camadas populacionais mais pobres do país, muitos rapazinhos não encontram outras opções, diante da família e da sociedade, para viver sua homossexualidade. Na quase totalidade dos casos, quando manifestam tendências homossexuais, são expulsos de seus lares ainda muito jovens, depois de sofrerem assédios, espancamentos e estupros múltiplos. (Trevisan, 2011, p. 417)

O autor analisa, acertadamente, o destino que muitas travestis têm na cidade, mas incrementando esse pensamento, é possível inferir que para além das originariamente citadinas, há aquelas que pelos mesmos motivos elencados por ele, fazem a migração forçada de pequenas e médias cidades do interior rumo às grandes metrópoles (Vasconcelos, 2017) como forma de fugir da opressão, mas normalmente encontram destinos semelhantes quando a elas chegam, pois é na periferia que encontram abrigo e mais opressão, dessa vez não somente de gênero, mas social, econômica e cultural, impossibilitando que o leque de opções seja ampliado (Trevisan, 2011).

No tocante a essa fuga rumo às cidades, Didier Eribon (2008) afirma que os homossexuais percebem desde a mais tenra idade que a geografia é uma faca de dois gumes, pois ao perceberem que seu local de nascimento é limitador em termos físicos, concluem que a ideologia reinante também o é. Sabedores disso, eles elaboram planos de fuga para lugares maiores, onde pensam exercer sua homossexualidade sem o peso da homofobia. Evidentemente, o autor, francês, analisa na obra citada as grandes metrópoles, como Paris, Londres e Nova York e como as três foram transformadas na idolatria gay de destinos amigáveis e da plena realização do estilo de vida homossexual 
(Eribon, 2008). O autor, sendo mais específico, afirma:

[...] a cidade é também um mundo social, um mundo de socialização possível, e ela permite superar a solidão tanto quanto o anonimato. Um homossexual que decide ir viver numa cidade grande agrega-se àqueles que seguiram esse percurso antes dele e faz existir um mundo que o atrai e com o qual ele, com frequência, sonhou muito tempo antes de poder ter acesso. Por isso é que há uma espécie de exaltação, misturada com apreensão, é claro, nos primeiros tempos da descoberta de todas as possibilidades oferecidas pela cidade. (Eribon, 2008, p. 34)

A essa perspectiva se enquadram muitas travestis que se prostituem no bairro do Reduto, uma vez que um número significativo delas é oriunda do interior do Estado, de cidades pequenas, algumas destas bem distantes do eixo rodoviário, como as que se situam na Ilha do Marajó, local de onde saiu Josy Kimberly, travesti que fugiu de casa aos doze anos, pegando carona num "regatão" rumo a Belém, sina parecida com a de muitas outras travestis que se prostituem na capital paraense (Vasconcelos, 2017).

Não obstante, para o homossexual citadino ou o radicado na cidade, viver na urbe não foi exatamente o imaginado quando da fuga. Eribon (2008) preconiza o "discurso conservador" que espreita toda e qualquer ação desses indivíduos, desde seu local de moradia, passando pelas relações aí estabelecidas e desaguando na percepção de que eles, "homossexuais, (como) estão condenados à cidade, também estão condenados a tudo o que a cidade pode trazer consigo de violência" (Eribon, 2008, p. $57)$.

\section{Considerações}

As análises aqui expostas tiveram a intenção de trazer para o debate a territorialidade da travestilidade, que sobrevive através do tempo, mesmo ladeada de imaginários, muitos cerceadores e limitadores, no histórico bairro do Reduto, na cidade de Belém. É nela, cidade, que essas pessoas performatizam seus corpos e personas, criando e recriando identidades. A cidade aqui mostrada, Belém, e seu microcosmo, o bairro do Reduto, tornam o debate ainda mais instigante, pois os imaginários atravessam o tempo e cristalizam no senso comum verdades que teimam em ocultar o prefixo de negação "in" quando caminho outro não há.

Mesmo que avanços possam ser percebidos na vivência da homossexualidade na cidade, é latente que essa vivência obedece preceitos caracterizadores de diferença, pois enquanto é permitido que o homossexual heterossexualizado conviva pacificamente em meio à heteronorma, desde que mantenha esse ideal (Miskolci, 2011), àqueles que subvertem essa lógica é reservado o degredo na degradação, como é o observado no caso das travestis, que sobrevivem, durante o dia, nos confins da sociedade, e durante o período noturno, em guetos e bairros decadentes.

Quando esses subversivos afrontam o poder instituído, como percebido na fala do representante do GHP, movimentos de contenção são elaborados para que a ameaça seja contida, que pode ser um afastamento para áreas cada vez mais distantes, ou mesmo ações físicas, quase nunca classificadas como homofobia. O Grupo Gay da Bahia (GGB) divulgou um relatório referente aos anos de $2017-2018^{10}$ acerca dos

\footnotetext{
${ }^{9}$ Ator social no mundo amazônico que viaja pelos rios amazônicos em pequenos barcos e comercializa inúmeros produtos, de gêneros alimentícios a produtos de higiene pessoal, trocando-os por gêneros agrícolas ou produtos extrativistas, numa relação análoga ao escambo (McGrath, 1999).

10 "Assassinatos de homossexuais (LGBT) no Brasil: relatório 2018", disponível em:
} 
assassinatos perpetrados contra a comunidade LGBT no país e a região amazônica aparece no ranking da instituição com três Estados, sendo Roraima e Mato Grosso os líderes, em primeiro e segundo lugares, respectivamente, e o Amazonas em sétimo. $O$ relatório aponta, ainda, que dos assassinatos de travestis no mundo, 40\% foram registrados no Brasil, o que desestrutura a lógica pacifista criada sobre o país e as diversidades.

O relatório afirma, ainda, que a lógica da sociedade brasileira ainda é pautada na fixidez das fronteiras entre masculino e feminino e que na região amazônica, na qual a maioria das mortes foi detectada, isso é muito forte, pois os assassinatos, mais da metade, foram cometidos por membros familiares e dentro de casa. Especificamente sobre a violência física, letal ou não, é sobre travestis e transexuais, que a balança da intolerância tende a pender, pois são indivíduos que não ocultam suas identidades e as performatizam, sustentam suas histórias de vida no corpo, na indumentária, no gestual, dificilmente sendo ignoradas pela sociedade.

As travestis, seja as que sobrevivem tendo a prostituição como alicerce, seja as que buscam outras formas laborais, todas com histórico de violências, de fugas em busca de um porto seguro na cidade, além de lançar mão da performance enquanto ratificadora da identidade, encontram na fraternidade, com seus altos e baixos, a permanência na urbe, pois desterritorializadas da/na cidade natal, do seio familiar e do reconhecimento da cidadania, tanto interno, do grupo, como externo, da sociedade, são os laços fraternos que as manterão coesas no embate rumo ao reconhecimento social, mesmo que tais laços sejam mantidos com controle excessivo e mediados pela dança lenta das relações de poder.

\section{Referências}

BECKER, Howard. Outsiders. Estudos de sociologia do desvio. Rio de Janeiro: Zahar, 2008.

BRASIL. Ministério do Planejamento, Orçamento e Gestão. Instituto Brasileiro de Geografia e Estatística. Contagem Populacional. Disponível em: https://sidra.ibge.gov.br/pesquisa/estimapop/tabelas. Acesso em: 20/07/2019.

BRESCIANE, Maria Stella. A cidade das multidões, a cidade aterrorizada. In: PECHMAN, Robert Moses (org.). Olhares sobre a cidade. Rio de Janeiro: Editora UFRJ, p. 09-42, 1994.

CASTORIADIS, Cornelius. A Instituição Imaginária da Sociedade. Rio de Janeiro: Paz e Terra, 1982.

CASTRO, Fábio. A cidade Sebastiana: Era da Borracha, Memória e Melancolia numa Capital da Periferia da Modernidade. Belém: Ed. Labor, 2010.

DURAND, Gilbert. As estruturas antropológicas do imaginário. São Paulo: Martins Fontes, 2002.

ECO, Umberto. O Signo. Lisboa: Editorial Presença, 1985.

ERIBON, Didier. Reflexões sobre a questão gay. São Paulo: Companhia de Freud, 2008.

https://homofobiamata.wordpress.com/. 
FERREIRA, Rubens. Travestis em perigo ou o perigo das travestis? Notas sobre a insegurança nos territórios prostitucionais dos transgêneros em Belém (PA). Enfoques - Revista dos alunos do PPGSA da UFRJ, v 2, $n^{\circ}$ 1, julho de (2008), Disponível em: http://www.enfoques.ifcs.ufrj.br/ojs/index.php/enfoques/article/view/17. Acesso em: 02/04/2019.

GHP - Grupo Homossexual do Pará. Nova Cartografia Social da Amazônia: movimentos sociais e conflitos nas cidades da Amazônia. Fascículo 2. Homossexuais na cidade de Belém, 2013. Disponível em: http://novacartografiasocial.com/fasciculos/movimentossociais-e-conflitos-nas-cidades-da-amazonia/. Acesso em: 14/07/2019.

GOVERNO DO PARÁ. Secretaria de Segurança Pública, 2018. Disponível em: http://www.segup.pa.gov.br/relat\%C3\%B3rio-anual-do-sicpa. Acesso em: 10/06/2019.

GOVERNO DO PARÁ. Secretaria de Cultura. Belém da Saudade: A Memória da Belém do início do século em cartões postais. Belém: Secult, 2008.

HAESBAERT, Rogério. O mito da desterritorialização: do "fim dos territórios" à multiterritorialidade. Rio de Janeiro: Bertrand Brasil, 2009.

HOLANDA, Sérgio Buarque de. Raízes do Brasil. São Paulo: Companhia das Letras, 2010.

LOUREIRO, João de Jesus Paes. Cultura Amazônica: uma poética do imaginário. Belém: EdUFPA, 2010.

MCGRATH, David. Parceiros no Crime: o Regatão e a Resistência Cabocla na Amazônia Tradicional. In: Novos Cadernos NAEA, v. 2, n 2. p. 57-72. Belém: NAEA/UFPA, (1999), Disponível em: https://periodicos.ufpa.br/index.php/ncn/article/view/109. Acesso em: 05/02/2019.

MISKOLCI, Richard. O armário ampliado - notas sobre sociabilidade na era da internet. Gênero, Niterói: Núcleo Transdisciplinar de Estudos de Gênero - NUTEG, v. 9, n. 2, p. 171-190 (2011), Disponível em: http://www.revistagenero.uff.br/index.php/revistagenero/article/view/88. Acesso em: 17/02/2019.

MONTEIRO, Ana. Uma alternativa metodológica para a revitalização a partir da preservação da identidade morfológica - o caso do Reduto em Belém/PA. IV Seminário de história da cidade e do urbanismo. Belém: 2013.

MUNIZ, Jacqueline; PAES-MACHADO, Eduardo. Polícia para quem precisa de polícia: contribuições aos estudos sobre policiamento. Cad. CRH vol.23 no60. Salvador, 2010, Disponível em: http://www.scielo.br/scielo.php?script=sci_arttext\&pid=S010349792010000300001. Acesso em 30/11/2019.

OCHOA, Marcia. Ciudadanía perversa: divas, marginacíon y participación en la "localización". In: MATO, Daniel (coord.). Políticas de ciudadanía y sociedad civil en tiempos de globalización. Caracas: FACES, Universidad Central de Venezuela, PP. 239256, 2004.

PICOLI, Fiorelo. O Capital e a Devastação da Amazônia. São Paulo: Expressão Popular, 2008.

RIBEIRO, Miguel Ângelo. Território e Prostituição na Metrópole Carioca. São João de Meriti, RJ: Ed. Ecomuseu Fluminense, 2002. 
RODRIGUES, Edmilson. Os desafios da metrópole: reflexões sobre o desenvolvimento para Belém. Belém: NAEA/UFPA, 2000.

SARGES, Maria de Nazaré. Belém: riquezas produzindo a belle-époque (1870-1912). Belém: Paka-Tatu, 2002.

TOLEDO, José Júlio. Influência do solo e topografia sobre a mortalidade de árvores e decomposição de madeira em uma floresta de terra firme na Amazônia Central. Tese (doutorado). Manaus: Instituto Nacional de Pesquisas da Amazônia/Universidade Federal do Amazonas, 2009.

TREVISAN, João Silvério. Devassos no Paraíso: a homossexualidade no Brasil, da colônia à atualidade. São Paulo: Record, 2011.

TRINDADE JR, Saint-Clair Cordeiro da; SILVA, Marcos Alexandre Pimentel. (orgs.). Belém: a cidade e o rio na Amazônia. Belém: EDUFPA, 2005.

VASCONCELOS, Osvaldo. Josy Kimberly - narrativas em travessia: gênero, corpo, prostituição e ativismo solitário em Belém (PA). Revista História Oral, v20, n² 2, Rio de Janeiro, 2017, Disponível em: https://revista.historiaoral.org.br/index.php?journal=rho\&page=article\&op=view\&path\% 5B\%5D=722\&path\%5B\%5D=pdf. Acesso em 13/04/2019.

\section{Notas de autoria}

Osvaldo Vasconcelos é geógrafo, mestre em Comunicação e doutorando em História Social da Amazônia pela Universidade Federal do Pará - UFPA. E-mail: osvaldosvasconcelos@gmail.com.

\section{Como citar esse artigo de acordo com as normas da revista}

VASCONCELOS, Osvaldo. Reduto de travestis: das origens fabris ao repositório de imaginários de um bairro amazônico. Sæculum - Revista de História, v. 24, n 41, p. 426-440, 2019.

\section{Contribuição de autoria}

Não se aplica.

\section{Consentimento de uso de imagem}

Não se aplica.

\section{Aprovação de comitê de ética em pesquisa}

Não se aplica.

\section{Licença de uso}

Este artigo está licenciado sob a Licença Creative Commons CC-BY. Com essa licença você pode compartilhar, adaptar, criar para qualquer fim, desde que atribua a autoria da obra.

\section{Histórico}

Recebido em 04/08/2019.

Aprovado em 30/11/2019. 